Journal American Society of Mining and Reclamation, 2018 Vol.7, No.2

\title{
CONCEPTUAL MODEL FOR HYDROLOGY-BASED GEOMORPHIC EVAPOTRANSPIRATION COVERS FOR RECLAMATION OF MINE LAND $^{1}$
}

\author{
Z. F. Zhang ${ }^{2}$ N. Bugosh, T. Tesfa, M. J. McDonald, and J. A. Kretzmann
}

\begin{abstract}
Currently, there are about half a million abandoned mine sites in the U.S. and an estimated 15,000 in New Mexico alone. Surface mining imposes severe ecological effects on the land because it not only alters the vegetation, soils, bedrock, and landforms, but also changes the surface hydrology, groundwater, and flow paths that ultimately result in degraded ecology and water quality. Two relatively new methodologies, fluvial geomorphic landform design and evapotranspiration (ET) waste covers, offer solutions to reclaim these sites for long-term, maintenance-free reclamation. GeoFluv ${ }^{\mathrm{TM}}$ is a specific geomorphic grading design method that uses natural analogues for post-mining landscapes and uses design input values taken from stable natural landscapes to make a reclamation design that provides hydrological function, supports ecosystem integrity, and is cost-effective, sustainable, and more visually attractive. It has documented ability to produce surface runoff water quality at least equal to adjacent undisturbed lands and has been used for disturbed lands, including active and abandoned mine sites. Surface ET covers have been used to manage the subsurface hydrology above landfills, waste sites, and mine lands. ET covers protect the underlying materials against erosion, provide a medium for vegetation growth, store precipitation within the cover, and release the stored water into atmosphere so that the infiltration of precipitation is minimized. A conceptual design study is carried out based on an actual, typical abandoned mine site near Raton, New Mexico, to which common problem conditions at abandoned mine sites are assumed. The purpose of this study is to present the concept that covers can be designed by integrating two remediation technologies (geomorphic grading and ET cover) as a geomorphic ET (GET) cover to improve performance. The overall shape of the GET cover can mimic the natural topography of the surrounding area, while the thickness and layering of the cover can be optimized for best vegetation growth and infiltration control. The application of GET cover technology on mine land is expected to substantially improve the reclamation effects by coupling the benefits of the geomorphic cover (drainage reduction, runoff management, vegetation diversity) with the benefits of ET covers (vegetation growth and sustainability, percolation reduction, protection of surface and groundwater).
\end{abstract}

Additional Key Words: Tailings; Geotechnical; Water Management; Vegetation

1. Oral paper presented at the 2018 National Meeting of the American Society of Mining and Reclamation, St Louis, MO: The Gateway to Land Reclamation. June 2-7, 2018. Published by ASMR, 1305 Weathervane Dr. Champaign, IL 61821.

2. Fred Zhang, Environment Engineer; Teklu Tesfa, Scientist; Energy and Environment Directorate, Pacific Northwest National Laboratory, Richland, WA 99352. Nicholas Bugosh, GeoFluv, Inc., Parma, Ohio 44134. Meghan J. McDonald, John A. Kretzmann, New Mexico Abandoned Mine Land Program, Energy Minerals \& Natural Resources Department, Mining \& Minerals Division, 1220 South St. Francis Drive, Santa Fe, NM 87505.

Journal American Society of Mining and Reclamation, 2018 Volume 7, Issue 2 pp 61-88

DOI: http://dx.doi.org/10.21000/JASMR18020061 


\section{Introduction}

Currently, there are about half a million ${ }^{1}$ abandoned mine sites in the U.S. and an estimated $15,000^{2}$ in New Mexico. Surface mining imposes severe ecological effects on the land because it not only alters the vegetation, soils, bedrock, and landforms, but also changes the surface hydrology, groundwater, and flow paths (Nicolau and Asensio, 2000; Osterkamp and Joseph, 2000). Conventional reclamation of mining cuts and spoil banks nearly always have constantgradient slopes with benches. They are usually combined with elements to redirect and slow runoff (Bugosh, 2006; Nicolau, 2002; Nicolau, 2003). The main shortcoming of conventional designs is that they give little consideration to proper hydrologic function for balanced conveyance of water and sediment from the land surface (Bugosh, 2004). This practice may lead to accelerated erosion and the reclamation landforms may require long-term maintenance and repair.

Most natural hillslopes consist of a variety of shapes (concave and convex) interspersed with ridges and swales (Ayres et al., 2006). Drainage follows natural drop lines with catchment sizes defined by undulating relief on the hillslope. Vegetation on natural slopes grows in discrete units depending on factors such as hillside hydrogeology and microclimate effects. For example, in many areas trees and shrubs often grow in lower concave areas, where soil moisture is higher, while grasses generally appear at the upper, drier convex portions of a slope.

Many scientists and engineers favor geomorphic grading (GG) because nature can provide analogues for post-mining landscapes in terms of landscape stability (Hancock et al., 2003). Slope and landform design based on natural analogues is more functional, long-lasting, more visually attractive, and more cost-effective (Schor and Gray, 2007) than conventional reclamation.

Although GG can make the surface condition of a mine land visually similar to a natural landscape, the hydrological condition of the disturbed subsurface materials in the reclaimed area can be tremendously different from the undisturbed natural materials under natural conditions. Compared to the pre-mine consolidated rock, the loose backfill has much (by several orders of magnitude) larger hydraulic conductivity (Brady et al., 1998). The soil layer of a natural system usually takes thousands of years or longer to develop and has the properties to retain precipitation and provide conditions for vegetation growth. A newly graded land surface generally lacks the

\footnotetext{
${ }^{1}$ https://www.abandonedmines.gov/ep.html

2 http://www.emnrd.state.nm.us/MMD/AML/amlmain.html
} 
soil layers of the natural system. Often the measure taken to reduce erosion is to make very lowgradient slopes that enhance infiltration. Hence, the applicability of GG that uses this approach is in question for acid spoils and sites with acid mine drainage. Therefore, for better performance, geomorphic reclamation of mine land needs to consider and manage both the surface and subsurface hydrology.

Surface evapotranspiration (ET) soil covers use two natural processes to control infiltration into the underlying waste zone - the soil provides a natural water reservoir for precipitation, and natural evaporation and plant transpiration empty the soil water reservoir. An ET cover is a selfrenewing biological system and is expected to last much longer than the conventional compacted clay barrier. ET covers have been used above landfills (e.g., Albright et al., 2004; Apiwantragoon et al., 2015; Barnswell and Dwyer, 2011; Benson et al., 2001; Benson et al., 2007; Santini and Fey, 2014; Scanlon et al., 2005), waste sites (e.g., Bowerman and Redente, 1998; Gee et al., 1997; Link et al., 1995; Pettit et al., 1994; Rutqvist et al., 2011; Scanlon et al., 1997; Waugh et al., 2010; Waugh et al., 2007; Wing and Gee, 1994; Zhang, 2015), and mine lands (e.g., Barber et al., 2015; Meiers et al., 2015; O'Kane and Wels, 2003; Zhan et al., 2006). The function of an ET cover is to protect the underlying materials, provide a medium for vegetation growth, store precipitation within the cover, and release the stored precipitation later into the atmosphere so that the infiltration of precipitation waste zone is minimized. The storage capacity of an ET cover can be further enhanced by including a capillary break beneath the storage layer. A properly designed ET cover can considerably reduce or eliminate the percolation of precipitation through the underlying mine material and hence reduce or eliminate acid mine percolation. However, the ET cover will not affect groundwater-caused acid generation if groundwater flows through the mine material. This is beyond the scope of this study.

This paper presents the concept of the geomorphic evapotranspiration (GET) cover. A conceptual design study of the GET cover focusing on geomorphic grading is demonstrated at an actual mine site. The GET cover is expected to minimize hazardous mine drainage/percolation and prevent degradation of water quality in the discharge area. 


\section{The Geomorphic Evapotranspiration (GET) Cover}

\section{Concept}

A typical ET cover (Fig. 1a) consists of five components, which are, from top to bottom, an erosion-control layer, a water storage layer, a drainage layer, a barrier layer, and a foundation layer. The major functions of these layers are as follows:

- The erosion-control layer resists wind- and water-caused soil erosion.

- The water storage layer is the medium for vegetation growth and stores infiltration water for vegetation growth and for reduction of percolation.

- The drainage layer is sometimes placed below the storage layer and above the barrier layer to remove excessive water from the storage layer and improve slope stability. The layer may deter intrusion of roots, animal burrowing, and/or human digging.

- The barrier layer minimizes percolation of water through the underlying waste by impeding water flow through it and promoting flow in the drainage layer. The barrier layer also restricts upward movement of any gases or volatile constituents that might be emitted by the waste.

- The foundation layer supports upper layers and heavy construction equipment.

Table 1 summarizes the possible components, their functions, and typical construction materials of a GET cover. Some layers may contain several sub-layers or materials. For example, a barrier layer may be composed of a geomembrane and a clay liner that together form a composite liner. Some layers may be combined. For example, the erosion-control layer and the water storage layer may be combined by mixing a proper fraction of gravels or cobbles with the soil. Not all components are needed for all GET covers. The simplest GET cover may only contain the storage layer. Additionally, the layers do not have to be laterally continuous and the thickness of the layers can vary.

The GG in mining reclamation makes the final landform geomorphologically and visually compatible with the surrounding area and remains stable for the long term (Fig. 1b) while the properly designed ET cover can isolate problem waste material and control its release of pollutants and further helps to manage the fate of precipitation and vegetation growth.

The fluvial geomorphic grading that is stable against erosion and promotes sustainable land development is based on the essential landform characteristics of stable lands in the surrounding 
area. The landform characteristics include those that are in an equilibrium condition of hydrology and ecology (Bugosh, 2009):

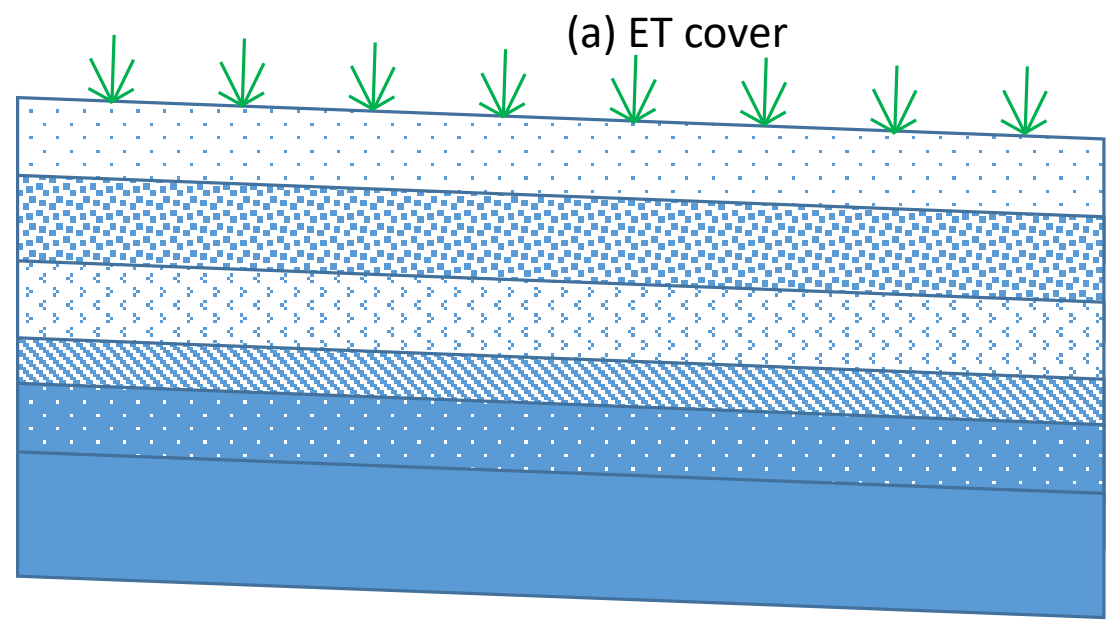

\section{Erosion-Control Layer \\ Water Storage Layer \\ Drainage Layer \\ Barrier Layer \\ Foundation Layer \\ Mine Waste}
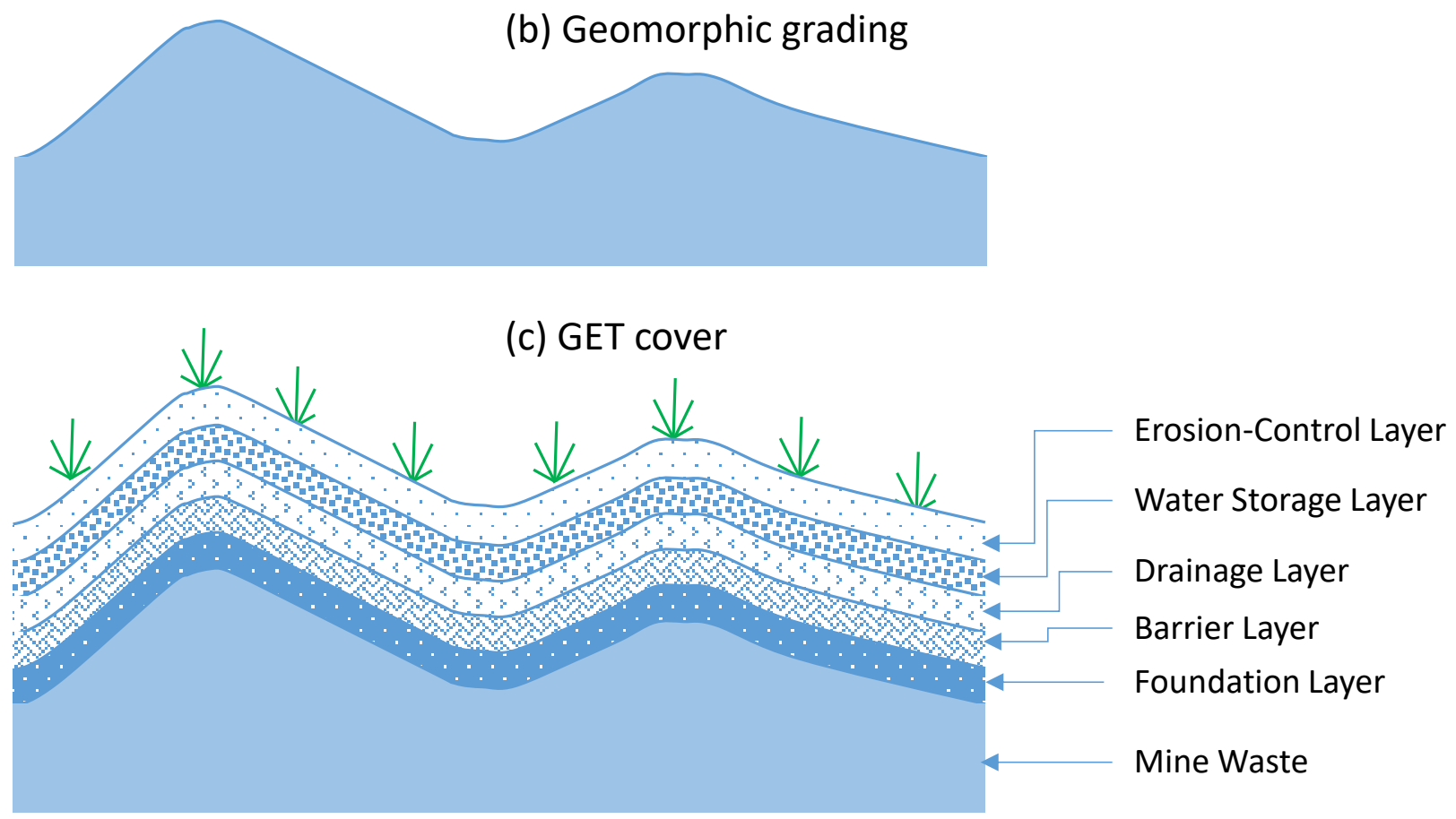

Figure 1. Schematic of an ET cover, geomorphic grading, and a GET cover.

A GET cover (Fig. 1c) is a combination of a surface cover (Fig. 1a) and geomorphic grading (Fig. 1b). 
Table 1. The possible components, their function, and typical construction material of a GET cover (Modified after Rumer and Ryan, 1995).

\begin{tabular}{|c|l|l|}
\hline Layer & \multicolumn{1}{|c|}{ Primary Function } & \multicolumn{1}{|c|}{ Typical Materials } \\
\hline Erosion-control layer & Resist wind and water erosion & $\begin{array}{l}\text { Gravels, cobbles, paving } \\
\text { materials; geosynthetic } \\
\text { erosion control materials }\end{array}$ \\
\hline Storage layer & $\begin{array}{l}\text { Medium for vegetation } \\
\text { growth and stores infiltration } \\
\text { water }\end{array}$ & $\begin{array}{l}\text { Soil, recycled or reused waste } \\
\text { materials; organic materials }\end{array}$ \\
\hline Drainage layer & $\begin{array}{l}\text { Remove excessive water from } \\
\text { the storage layer and improve } \\
\text { slope stability; deter intrusion } \\
\text { of roots, animal burrowing, } \\
\text { and/or human digging }\end{array}$ & $\begin{array}{l}\text { Sand, gravel, or cobbles; } \\
\text { geonet or geocomposite }\end{array}$ \\
\hline Barrier layer & $\begin{array}{l}\text { Minimize percolation of } \\
\text { water through the underlying } \\
\text { waste; restrict upward } \\
\text { movement of any gases or } \\
\text { volatile constituents }\end{array}$ & $\begin{array}{l}\text { Compacted clay, } \\
\text { geomembrane, geosynthetic } \\
\text { clay liner, waste material, } \\
\text { asphalt }\end{array}$ \\
\hline
\end{tabular}

- Local base level elevation

- Slope at the local base level elevation

- Slope steepness and aspect

- Drainage density

- Channel longitudinal profile

- Ridge to head of channel distance

- Stream plan view geometry (e.g., radius of curvature, meander length, sinuosity, meander belt width, and "A-channel” reach length)

- Stream width to depth ratio 


\section{Hydrology-Based GET Cover Design}

The design of a GET cover is not simply placing a cover on the waste site. The complexity and design of a GET cover is dependent on numerous factors such as climate, vegetation, animal activities, waste types, and surface water/groundwater (SW/GW) conditions. The specific physical and chemical properties of the problematic waste material that is to be isolated plays a significant role in the cover design. In most cases, if the waste contains contaminants, then the infiltration water can mobilize contaminants in the waste. Furthermore, the infiltration water may react with some waste materials (e.g., rocks) and produce contaminated drainage. Hence, besides other functions, a main function of the GET cover is to manage the flow from a precipitation event. The general guidance is to reduce infiltration and percolation through the waste. The overall goal is to protect the groundwater below the waste and streams near the site.

\section{GET Cover Design}

A GET cover needs to be designed to meet mine closure objectives. The objectives of a cover may vary from site to site but generally include the following:

- Regulatory requirements related to groundwater, surface water, soil, and air. The release of contaminants to the environment should be below the regulatory limits.

\section{- Cover functional requirements.}

- Erosion control. The cover physically stabilizes the waste and provides dust and erosion control, e.g., with vegetation, a gravel layer, and/or a soil/gravel mixture.

- Medium for vegetation. The cover provides a medium for plant growth. The vegetation has multiple functions. It can tremendously reduce wind and water erosion of soil, stabilize the slope, consume the stored infiltration water, and release the water back to the atmosphere. The vegetation may also be a component of the ecological system and provide habitat for animals.

- Hydrological control. The cover has proper capacity to store infiltrated precipitation so that the water does not infiltrate through the waste zone but instead can be consumed by the vegetation. It may also allow runoff during a storm or drainage event if the water storage capacity is exceeded. In the design, percolation should be reduced to the 
Journal American Society of Mining and Reclamation, 2018 Vol.7, No.2

lowest level as practical. The storage capacity of the soil layer can be enhanced by including one or more capillary breaks below the soil.

- Gas control. The cover may also contain a specific layer to control the release of hazardous gas or the ingress of oxygen in order to control the oxidation of some minerals.

- Minimal maintenance. The GET cover is expected to function like a natural system and needs little maintenance under the site climate. The cover is expected to withstand extreme weather. Hence, the design of the GET cover needs to be optimized to meet the regulatory and functional requirements while still being cost-effective.

- Land use. The surface cover must meet the final land-use objectives. Often, the objective is to establish the pre-mining ecosystems and land uses. A GET cover requires vegetation at the ground surface, but it does not require the vegetation to be of a specific type.

The key to GET cover design is water balance, which is influenced by many factors such as climate, soil type, and hydrologic setting (e.g., depth of direction of groundwater table and flow direction). The mining activities create landforms and waste piles that are not in equilibrium with the surrounding environment. The GET cover can be designed to re-establish the equilibrium conditions of landform and hydrology. This can be achieved by proper GET cover design so the system is in harmony with the watershed hydrology and does not export any harmful constituents to the surrounding environment.

\section{Geomorphic Grading Design}

Landform design is fundamental component in the GET cover design. Poor surface water management and landform instability are common factors leading to failure of landforms or cover systems. One critical reason for the failure is that the engineered structures are constructed in the way that opposes the natural processes rather than based on natural analogues that integrate with the hydrology and ecosystem of the surrounding setting (Ayres et al., 2006).

Using the characteristics of a stable landform of the surrounding area as inputs, GG can be designed, e.g., using the GeoFluv ${ }^{\mathrm{TM}}$ fluvial geomorphic landform design method (Bugosh, 2004; Bugosh, 2009), so that the GG is similar to the stable landform of the surrounding area. The 
GeoFluv $^{\mathrm{TM}}$ method has been incorporated into Natural Regrade ${ }^{1}$ (Carlson Software Inc., Maysville, KY, USA), an Office of Surface Mining Technical Innovation and Professional Services Core Software, for simplified calculations, integration of input values, and a cohesive landform design. Natural Regrade can make and display topographic maps and three-dimensional (3-D) images of the landscape design and calculating volumes and cut/fill material balance for designs. It also enables the user to evaluate landscape design alternatives by selecting the optimum design for bond alternatives, construction costs, changing mine plans, land use, and other factors.

The GeoFluv ${ }^{\mathrm{TM}}$ method has been successfully applied in the semi-arid western US (e.g., Bugosh, 2009; Calle and Stauffer, 2009; Clark, 2008; Eckels and Bugosh, 2010) and in other climates in the U.S. and internationally. Its application at the Log Creek Church abandoned mines project in Indiana won the 2008 Mid-Continent Region Award for Abandoned Mine Reclamation by the Office of Surface Mining Reclamation and Enforcement. ${ }^{2}$ Assessment of its application to the wetter eastern U.S. has been investigated (e.g., Bise and Murray, 2013; Hopkinson et al., 2012).

\section{Watershed Hydrology}

Before designing a GET cover, it is necessary to understand how a waste site affects the SW/GW near the waste site. Generally, contaminated percolation and/or drainage from the waste flows into and contaminates the SW/GW system. The monitoring data of the SW/GW system will be very helpful but are often insufficient. This problem can be addressed by conducting numerical simulation of SW/GW flow at the watershed scale. The simulation will estimate the SW/GW flow rates, flow directions, and SW/GW interaction at different locations and seasons under different climatic conditions. The simulation can provide the initial and boundary conditions for a site-scale simulation, to be discussed later.

The Soil and Water Assessment Tool (SWAT; Arnold et al., 1998) model is a physically-based, effective tool designed to predict the effect of management on water and sediment chemical yields in a watershed. Developed over three decades, it has gained international acceptance as a robust watershed modeling tool. In the United States, SWAT has been used in various applications; for example, evaluation of effectiveness of conservation practices within the USDA Conservation Effects Assessment Program (CEAP, 2007) initiative and supporting Total Maximum Daily Load

\footnotetext{
${ }^{1}$ http://www.carlsonsw.com/solutions/mining-solutions/natural-regrade/

2 https://www.osmre.gov/programs/awards/AMLwinners.shtm.
} 
analyses (Borah et al., 2006). Numerous studies (over 2200 journal articles $^{1}$ ) have reported successful applications of SWAT for reproducing observed hydrologic and/or pollutant loads across a wide range of watershed scales and environmental conditions, as well as its applications in assessing impacts of conservation practices, land use, climate change, water management, and other scenarios (Gassman et al., 2007).

\section{Site-Scale Hydrology}

The hydrology at the waste site is dramatically affected by the watershed hydrology, the grading of the waste, and the cover design. The design options of the GET cover for a site can be evaluated by a numerical simulator that is capable of incorporating transport of water, air, contaminants, and energy in a GET barrier and the underlying waste. The watershed simulation results can be used as the boundaries for the site-scale simulation. The GG is used as the base for investigating GET cover options.

Pacific Northwest National Laboratory has developed the STOMP (White et al., 2015) numerical simulator, which was specifically designed to provide multidimensional analysis capabilities for modeling subsurface flow and transport phenomena. A simulator such as STOMP can be used to investigate the impacts of surface cover on the flow and contaminant transport in the waste sites (e.g., Freedman et al., 2002; Zhang et al., 2004; Zhang et al., 2005; Zhang et al., 2003; Zhang and Xie, 2006).

\section{$\underline{\text { Demonstration }}$}

The concept of the hydrology-based GET cover is to be demonstrated at the Tin Pan mine site near Raton, NM, with computer simulations. The actual construction is beyond the scope of this study. Tin Pan Canyon coal mine workings consist of one closed adit and two coal gob piles (Fig. 2, Fig. 3). Actual mining of the coal may have started in 1906 and operations ceased before 1949. This site was selected for the demonstration because it has many of the common characteristics of abandoned mine sites: a remote location that makes importation of construction equipment difficult and expensive and waste materials deposited near the surface and groundwater. The site, watershed, and preliminary GG design are described below.

\footnotetext{
${ }^{1}$ https://www.card.iastate.edu/swat_articles
} 
Journal American Society of Mining and Reclamation, 2018 Vol.7, No.2

\section{The Tin Pan Mine Site}

The Tin Pan gob is located at $36^{\circ} 56^{\prime} 30.47^{\prime \prime} N, 104^{\circ} 32^{\prime} 16.51^{\prime \prime}$ W (Fig. 2, Fig. 3). The Tin Pan waste site, shown in a 3-D contour view in Fig. 4, lies within the smaller circle and covers about 1 hectare. The larger circle encompasses the 12.6-hectare upslope area that generates storm water runoff that drains through the waste site. The waste piles are in the foreground at the mouth of the tributary stream's valley at its confluence with Tin Pan Canyon stream (Fig. 3). The road angles upward across the contours from the lower right to behind the disturbed area and then exits midslope at the left (western) side (Fig. 3). 
Journal American Society of Mining and Reclamation, 2018 Vol.7, No.2

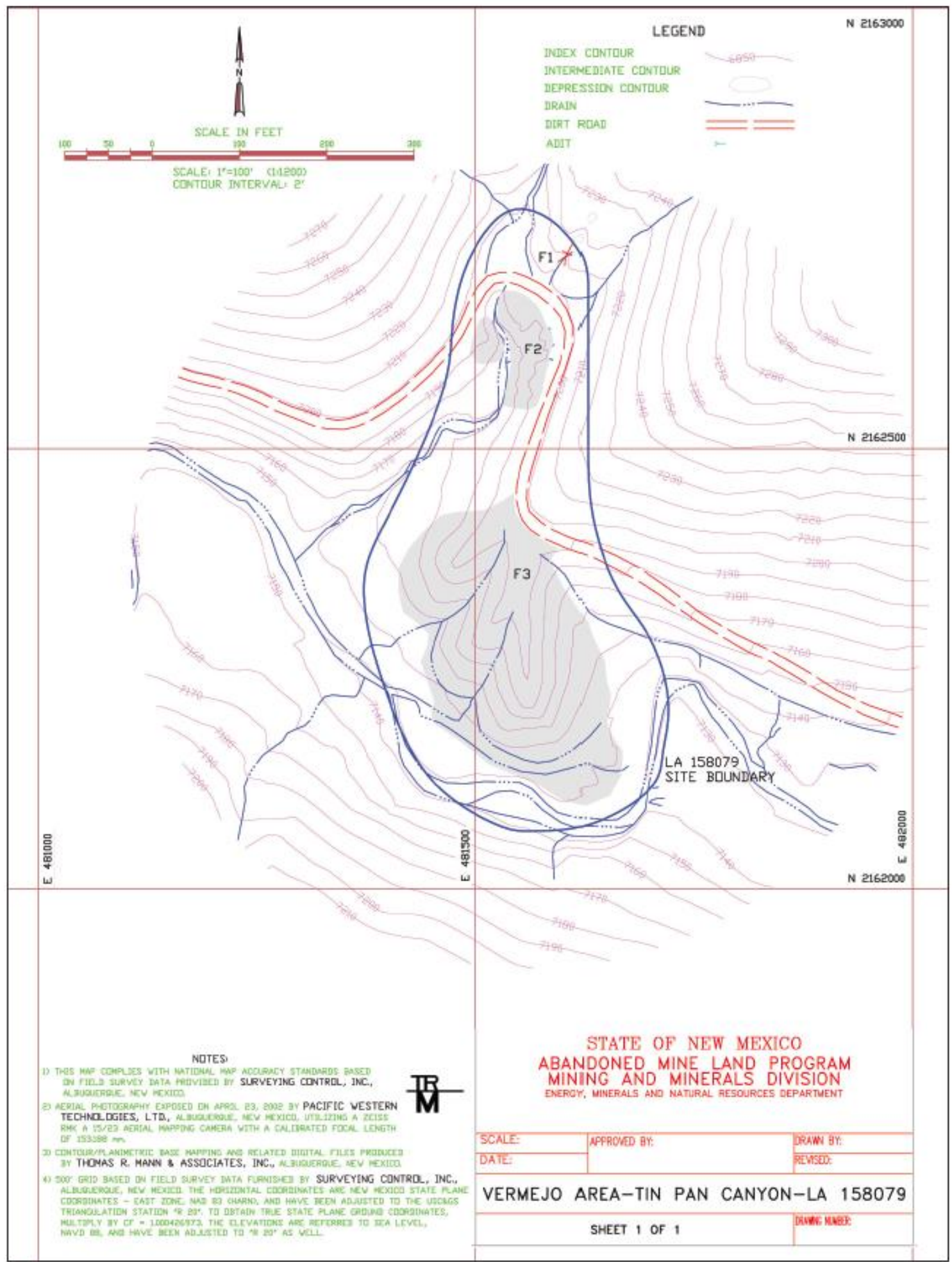

Figure 2. Location of coal gob piles (F2 and F3) at Tin Pan Canyon. The shaded areas indicate gob piles F2 and F3, the parallel dashed lines indicate the valley road referred to in Fig. 4, and the dash-dot lines crossing F2 and identified as "drain" in the legend depict the course of the existing, disturbed-site runoff channel identified by the lower arrow in Fig. 4 and again by an arrow in Fig. 8a. 


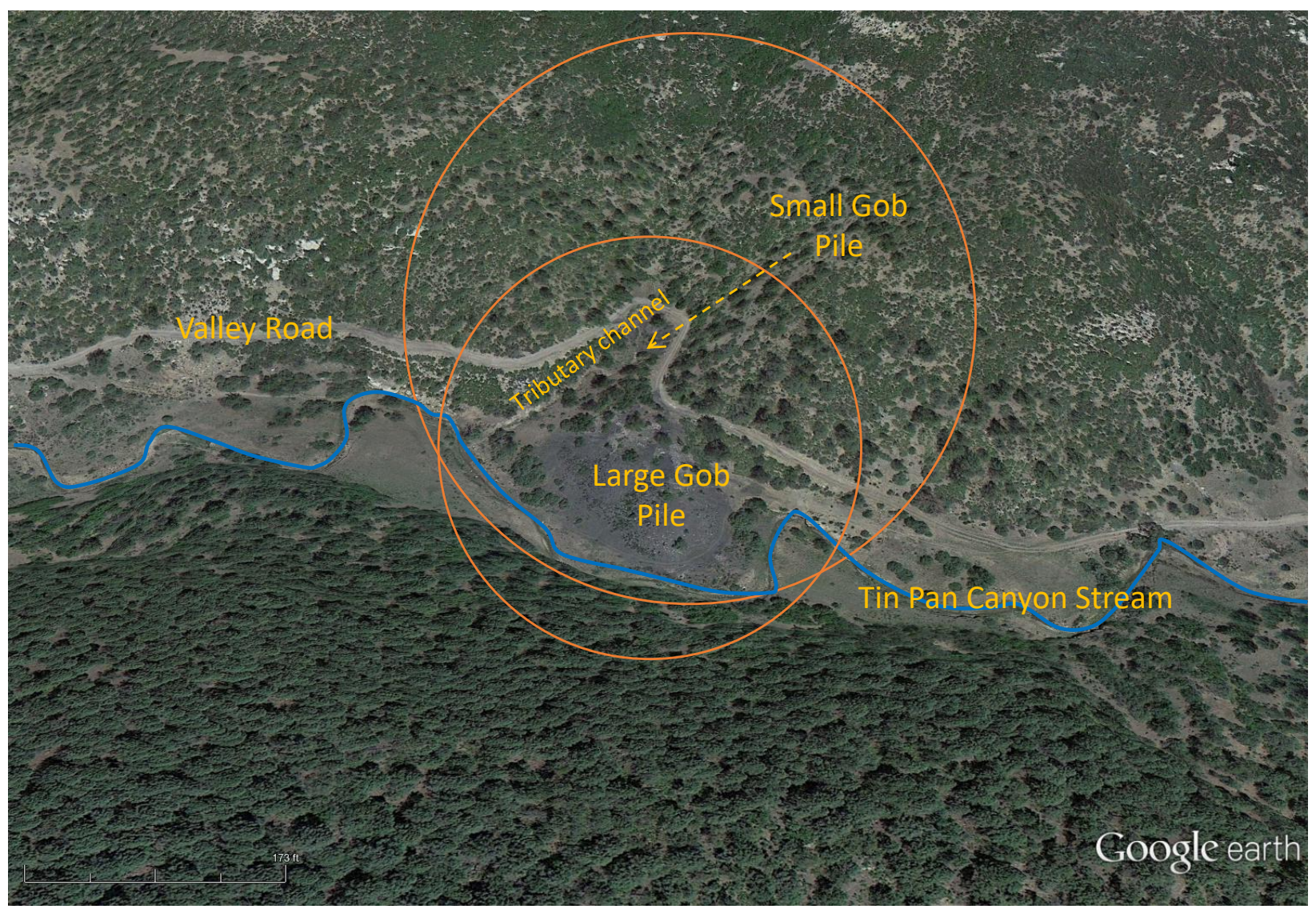

Figure 3. The Tin Pan mine site. The large circle indicates the upslope watershed and waste site to be considered in the design of geomorphic grading. The small circle encompasses the approximate area shown in the 3-D contour grading (Fig. 7), slope zone analysis (Fig. 9), and cut/fill map (Fig. 10). Please note that the image is not in uniform scale.

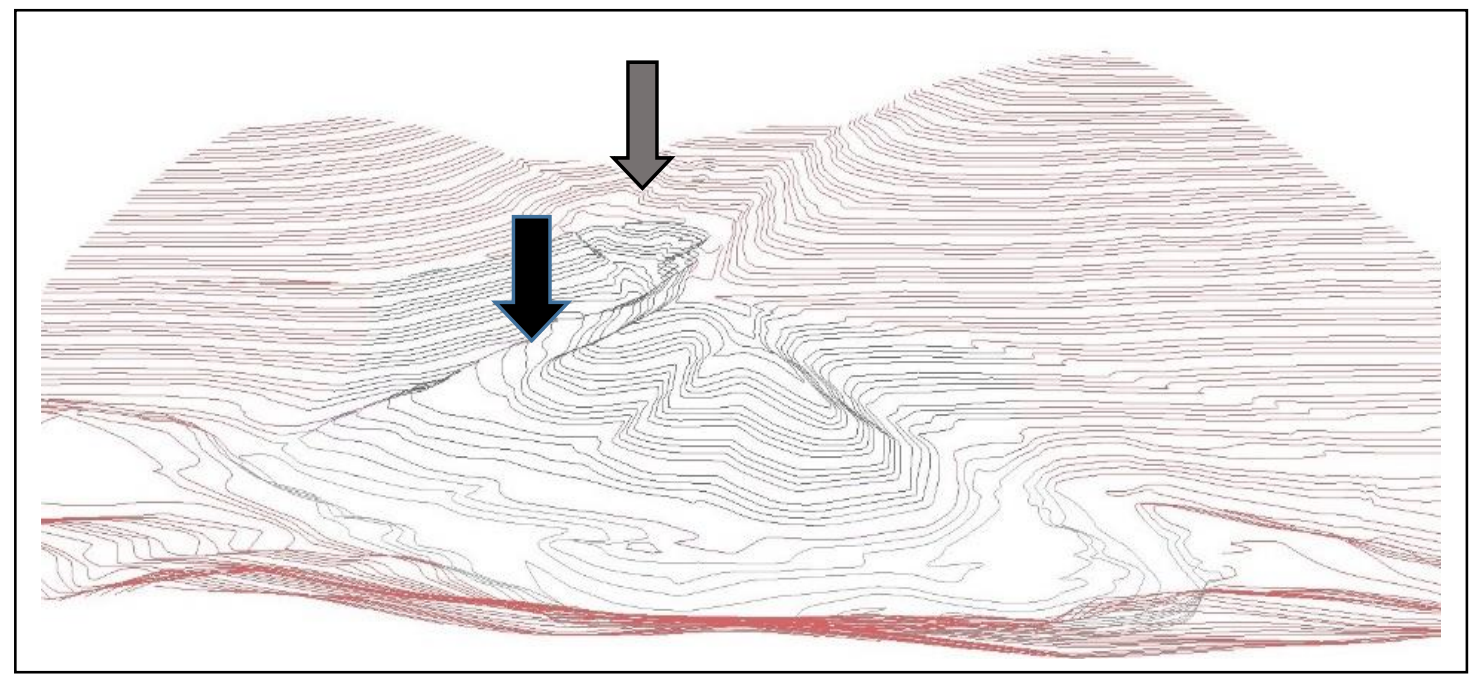

Figure 4. A 3-D contour view of the existing Tin Pan coal mine site. The view is south to north. The arrows show the location of the upper end of the site at the valley road crossing (gray, upper arrow) and the channel eroded into the waste along the west valley wall (black, lower arrow). 
The waste site consists of two gob piles of mine waste, a small pile (F2) and a large pile (F3) (Fig. 2). The Tin Pan Canyon stream flows by the large pile (Fig. 5). The total relief of the waste material on the large pile is about $14 \mathrm{~m}$. The actual bottom of the gob is unknown. The stream meandering is controlled by a thick, competent sandstone ledge that crops out immediately downstream of the gob pile. The rock cropping out on the skyline in the upper left of Fig. 5a in the tributary valley's watershed is characteristic of the thin soils over bedrock in the area. Thin soils over this bedrock combined with short-duration, high-intensity storms in this semi-arid region can produce large peak storm discharges.
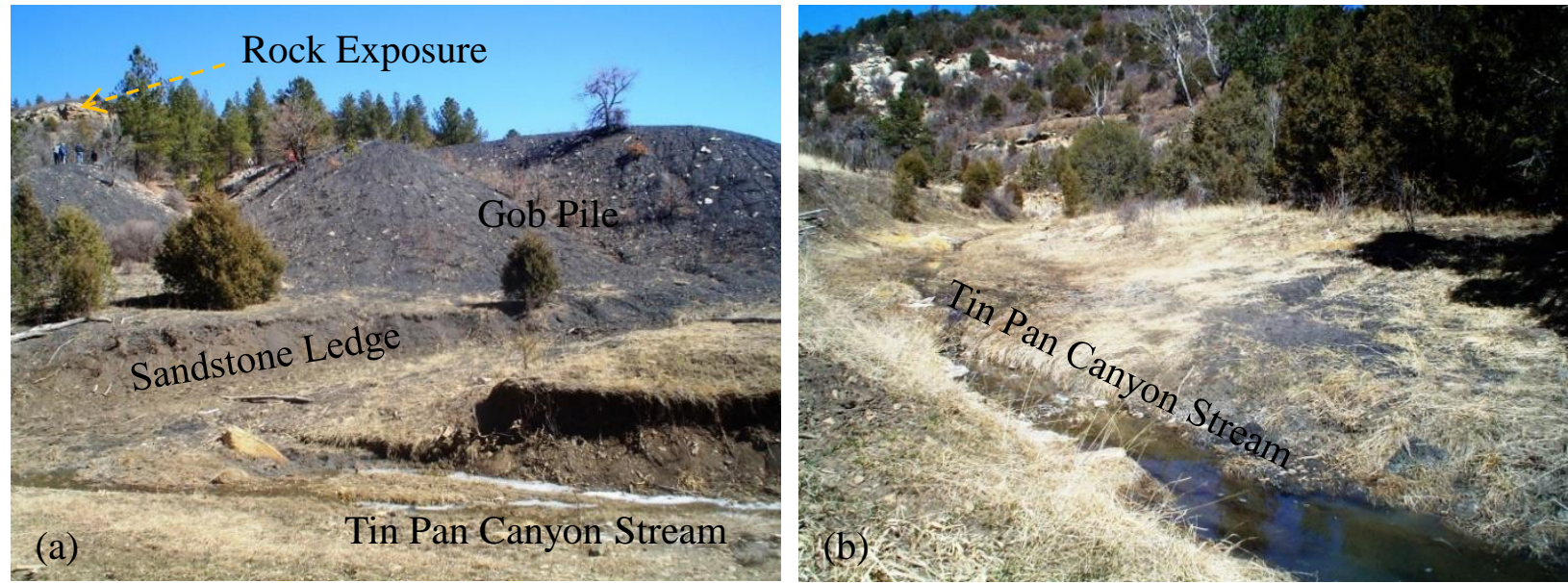

Figure 5. The large Tin Pan mine gob pile (a) and the Tin Pan Canyon stream by the gob pile (b). The total relief of the waste material on the gob pile is about $14 \mathrm{~m}$.

Hydrologic considerations for making a stable reclamation landform at the site include conveying the storm water discharges across the road at its low-water crossing and the slope steepness that could contribute to rill and gully erosion. The tributary channel (Fig. 3) discharges have eroded a gully along the west valley wall. The Natural Regrade inspector tool was used to estimate the erosive energy of the channel. Peak tractive force values of $32 \mathrm{~kg} \mathrm{~m}^{-2}$ at bank-full discharge and $78 \mathrm{~kg} \mathrm{~m}^{-2}$ at flood-prone discharges indicated the runoff could erode and transport unconsolidated material. Those estimates were supported by the observations of deep gullies eroded into the piles and waste material on the Tin Pan Canyon stream floodplain and in its channel.

The road that crosses the tributary valley at the upper end of the site (Fig. 3) comprises a significant knickpoint in the tributary channel's longitudinal profile. The stream's erosive energy will decrease as it flows across the flattened gradient of the road's low-water crossing and then abruptly increase as it drops off the road's downstream edge and on down the reclamation channel 
profile. Mitigation efforts for the erosive energy associated with this knickpoint must be made in the fluvial geomorphic channel design to protect the road crossing and the downstream channel.

\section{The Watershed}

The watershed area is delineated based on a $10 \mathrm{~m}$ digital elevation model extracted from U.S. Geological Survey data (https://lta.cr.usgs.gov/NED). The watershed is discretized into 23 subbasins with average size of $1.8 \mathrm{~km}^{2}$. The total size of the watershed is $41.6 \mathrm{~km}^{2}$, with elevation ranging from 2091.5 to $2457.2 \mathrm{~m}$ above mean sea level. Figure 6 shows the watershed location, the subbasins, the topographic pattern, stream network, and location of the Tin Pan mine site. The outputs from the coupled surface and subsurface modeling include surface runoff to streams, lateral flow to streams, groundwater flow to streams, recharge to groundwater, total soil water in the watershed, seepage from streams to the aquifer, total groundwater contained in the watershed, and total water added to streams. The SWAT-MODFLOW (Bailey et al., 2016) coupled hydrologic model will be used to simulate the surface and subsurface hydrology of the watershed where the Tin Pan site is located. The focus will be on the subbasin where the Tin Pan mine is located.
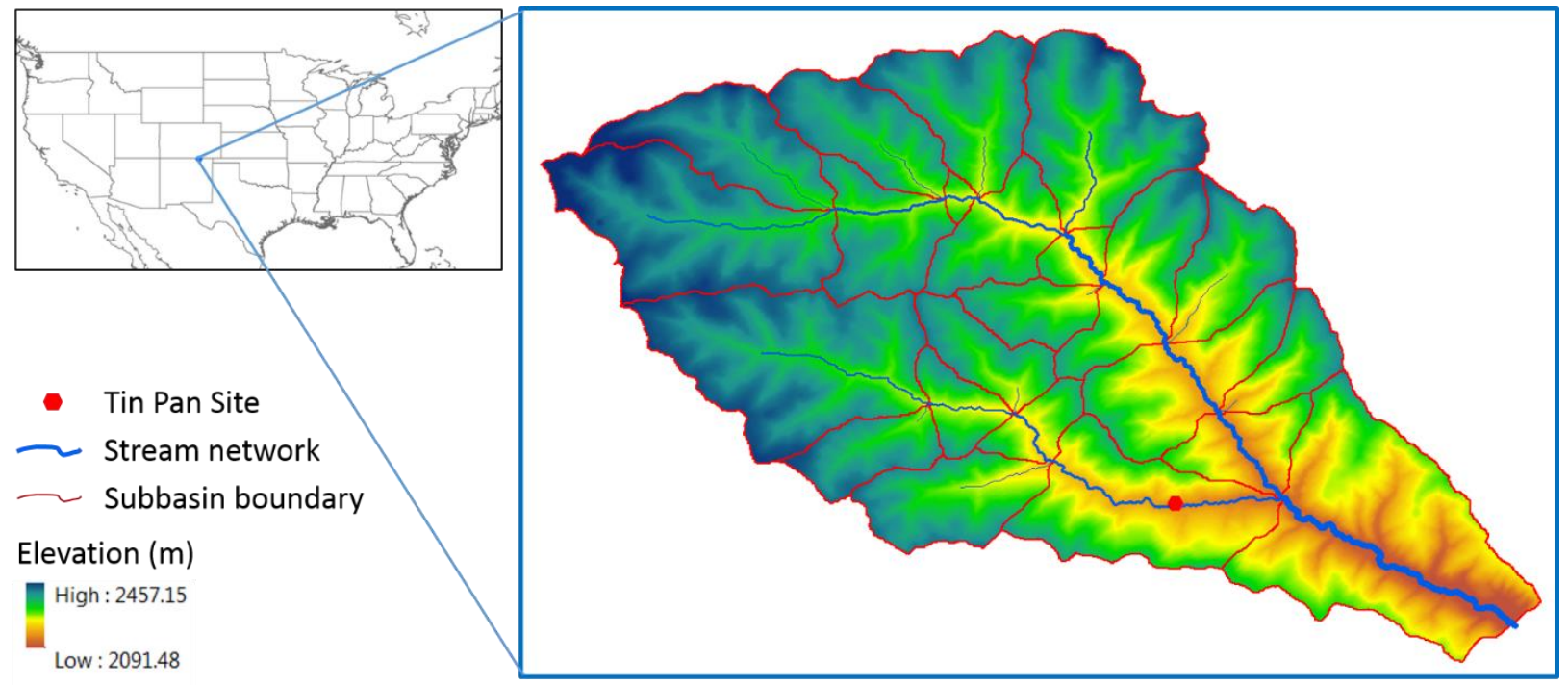

Figure 6. Watershed delineated for hydrologic simulation, elevation, subbasins, stream network, and the location of the Tin Pan mine site. The total size of the watershed is $41.6 \mathrm{~km}^{2}$.

\section{Geomorphic Grading}

The GeoFluv ${ }^{\mathrm{TM}}$ land reclamation design method is a patented approach based on fluvial geomorphology. The method uses inputs taken from natural reference sites in the surrounding 
area that have earth materials, climate, and vegetation similar to the disturbed project site, and that have attained high stability against erosion over thousands of years. The method is the heart of the Natural Regrade module, which was used to make and evaluate the reclamation designs. The designs have stream channels and upland areas that are fully integrated in three dimensions and that honor the fluvial geomorphic input parameters. One benefit of the computerized design is that designs can be relatively easily edited to conform to new site information, like a difference from the design assumptions for the bottom of the gob and the actual elevations discovered during excavation.

The Tin Pan site has special characteristics that need to be considered in the design, but that may also be encountered at other reclamation sites.

- The waste material was dumped into a narrow valley, making near angle of repose slopes where it is against the tributary channel valley walls and on its outer slopes approaching Tin Pan Canyon stream (Fig. 3 and Fig. 4).

- A pioneered two-track valley road along the Tin Pan valley is still in use and follows the north valley wall defining the upper end of the site, and it is desired to remain with a lowmaintenance at low water crossing (Fig. 3 and Fig. 4).

- The watershed area of the tributary valley above this road, because of the shallow soils over bedrock and minimal vegetation cover, has a high runoff coefficient that can result in erosive storm water discharges crossing the waste piles.

- Cultural resources may be present around the piles, so it is not desirable to disturb them.

- There are limited areas for alternative waste disposal, making onsite final placement desirable. This means that a balanced cut and fill design that does not require material export is preferable.

- The GET cover had to be integrated into the design to sequester the designated waste volume.

The slope zone analysis of the existing waste piles on the site (Fig. 7) represents areas of different slope ranges as determined from a triangulated surface made from the site topographic map. The New Mexico Abandoned Mine Land (NM AML) Program reported good vegetation 
recovery on nearby sites on slopes with a steepness of less than 80 percent $^{1}$. They also noted that slopes having a southwest aspect were much slower to recover.

A target slope steepness for the project of $\leq 33$ percent was selected based on that experience. The dark blue color in Fig. 7 indicates that the site waste material slopes are predominantly in the steepest slope category (averaging $58.1 \%$ steepness) and only $43.2 \%$ of the slopes are in the target range of $\leq 33 \%$ steepness.

Previous field work in nearby areas provided the reference site input information for drainage density ( $83 \mathrm{~m} / \mathrm{ha} ; 110 \mathrm{ft} / \mathrm{ac})$, ridge to head of channel distance $(27 \mathrm{~m} ; 90 \mathrm{ft})$, and "A-channel" reach length (15 m/ha; $20 \mathrm{ft} / \mathrm{ac})$. Raton, New Mexico, about $10 \mathrm{~km}$ to the east, has the nearest weather recording station. The National Oceanic and Atmospheric Administration atlas data provided the precipitation event values for estimating the tributary channel discharges. The site topographic information came from an AutoCAD .dwg format file provided by the NM AML Program from its site survey, and from Google Earth for the upstream tributary watershed area.

\footnotetext{
${ }^{1}$ http://www.emnrd.state.nm.us/MMD/AML/documents/SugariteGobReclamationProjects_001.pdf.
} 


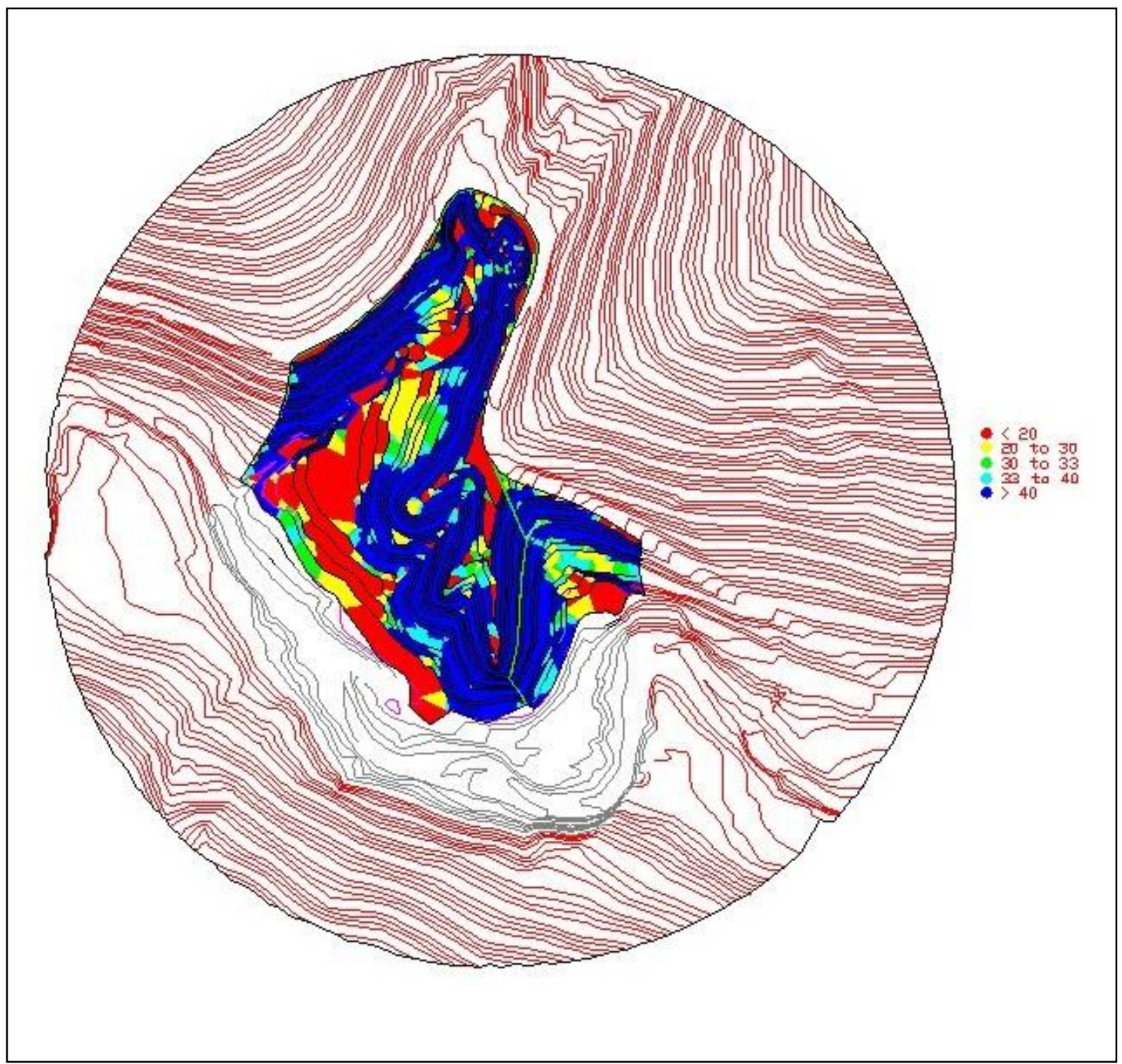

Figure 7. Slope zone analysis of the existing waste piles on the site. The legend shows the slope steepness (in percent) represented by the different colors. The actual design area for the reclamation design is $0.96 \mathrm{ha}$.

These data were used to make alternative draft designs. A change in almost any landform element affects the rest of the integrated 3-D design, but because the entire design can be revised relatively easily using a computer, many alternative designs, and variations of each design, can be investigated to find an optimal solution. We will simplify the discussion here to two main alternatives and refer to them as Alternatives \#1 and \#2. 

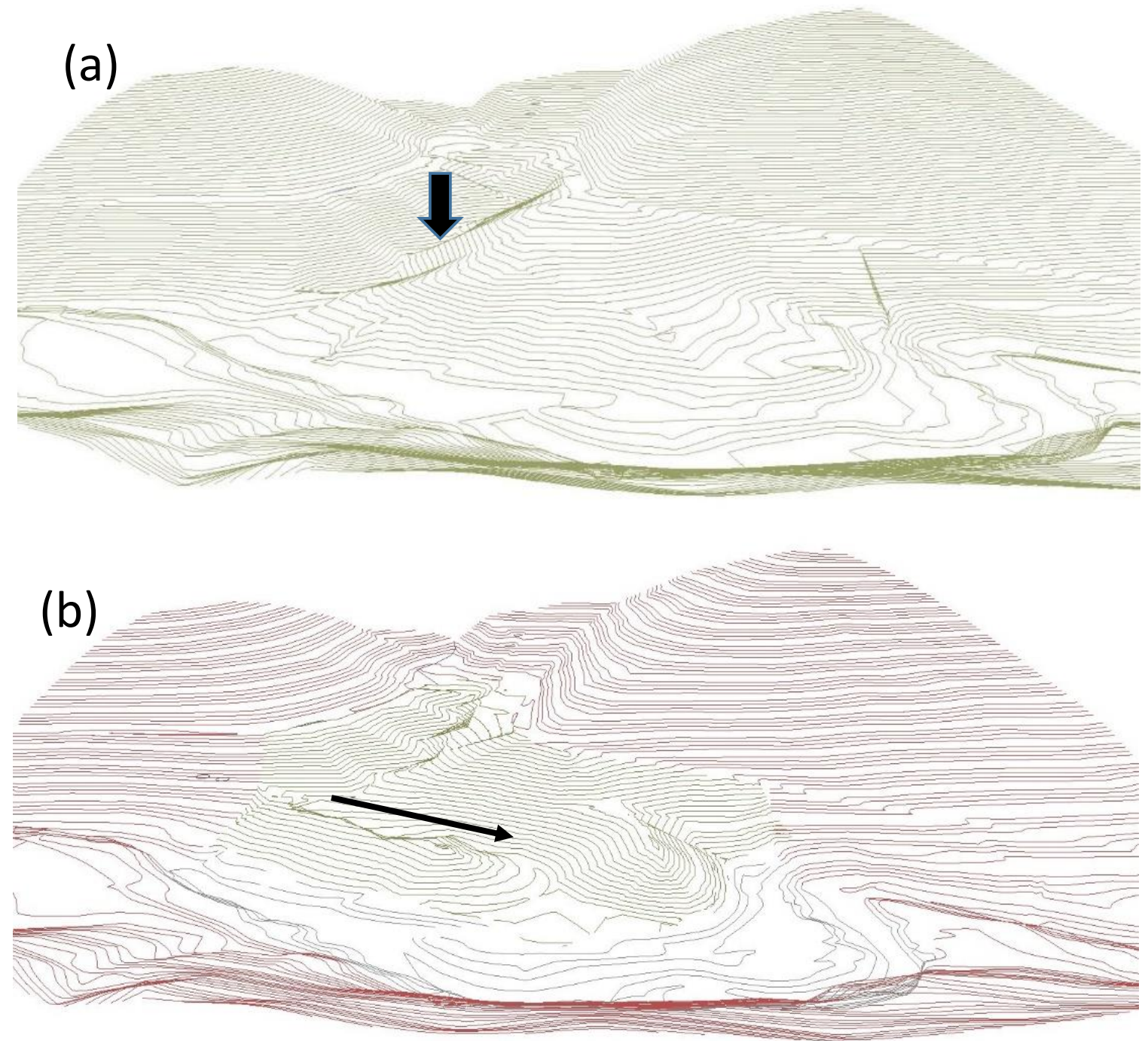

Figure 8. 3-D contour view of (a) Alternative \#1 for the site's fluvial geomorphic reclamation and (b) Alternative \#2 channel alignment that produced a fluvial geomorphic design that better meets all the site criteria. The view is south to north with Tin Pan Canyon stream in the foreground. The arrow in (a) indicates the tributary channel along the west valley wall. The arrow in (b) shows the change in valley direction from design Alternative \#1. The actual design area for the reclamation design is 0.96 ha.

The Alternative \#1 fluvial geomorphic reclamation design had a channel trending north to south over the waste to its confluence with the Tin Pan Canyon stream. Fig. 8a is a 3-D contour view of this design. This design confirmed that a reclamation landform based on the reference area input values could achieve a balanced cut to fill ratio that would eliminate the need for material import or export. Alternative \#1 also showed that steep slope areas could be reduced toward the target values. 
Stable natural stream channels in unconsolidated material develop a smooth concave longitudinal profile that helps dissipate the energy of increased discharge in the downstream direction by commensurately decreasing the slope. The tributary channel's tractive force values changed little with the better concave profile in Alternative \#1 because, despite the improved profile, the very steep average slope from the road crossing knickpoint to the channel's confluence with Tin Pan Canyon stream remained. This informed the decision to make alternative draft designs that would add channel length to decrease the channel's slope and tractive forces that led to Alternative \#2.

Alternative \#2 is the best fit for channel alignment to accomplish this reduction in slope and also meet the other project criteria of slope reduction, material balance, and accommodating the GET waste cover (Fig. 8b). As the channel enters the Tin Pan valley, it bends eastward and then turns southward to its confluence with Tin Pan Canyon stream. This appears to coincide with the original channel mouth location.

The added valley length in Alternative \#2 resulted in decreased channel tractive force values that decreased to $11 \mathrm{~kg} \mathrm{~m}^{-2}$ at bank-full, and $17 \mathrm{~kg} \mathrm{~m}^{-2}$ at flood prone, discharges at a point $71 \mathrm{~m}$ downstream of the road crossing knick point and maintained values in this low range as flow continued across the waste to the channel's mouth. Further work will investigate if additional tractive force reductions are possible immediately below the road crossing and recommend mitigation measures to protect the channel if further reductions are not possible.

Alternative \#2 was then edited to move slope reductions toward the targeted values and to verify that the material balance would not only eliminate the need for material import and export, but also allow for the target waste volume to be placed in the GET cover outside of the channel's flood-prone area. Figure 9 shows the slope zone analysis of the revised design. The target range in this analysis was set at $\leq 33$ percent steepness. Alternative \#2 increases the fraction of slopes that are in the target range from only $43 \%$ in the existing topography to $71 \%$. The fluvial geomorphic design also produces a much more varied topography than the existing site depicted in Fig. 7, resulting in a mosaic of slopes that promotes variation in vegetation species diversity and composition through variation in sunlight and soil moisture (Clark, 2008). 


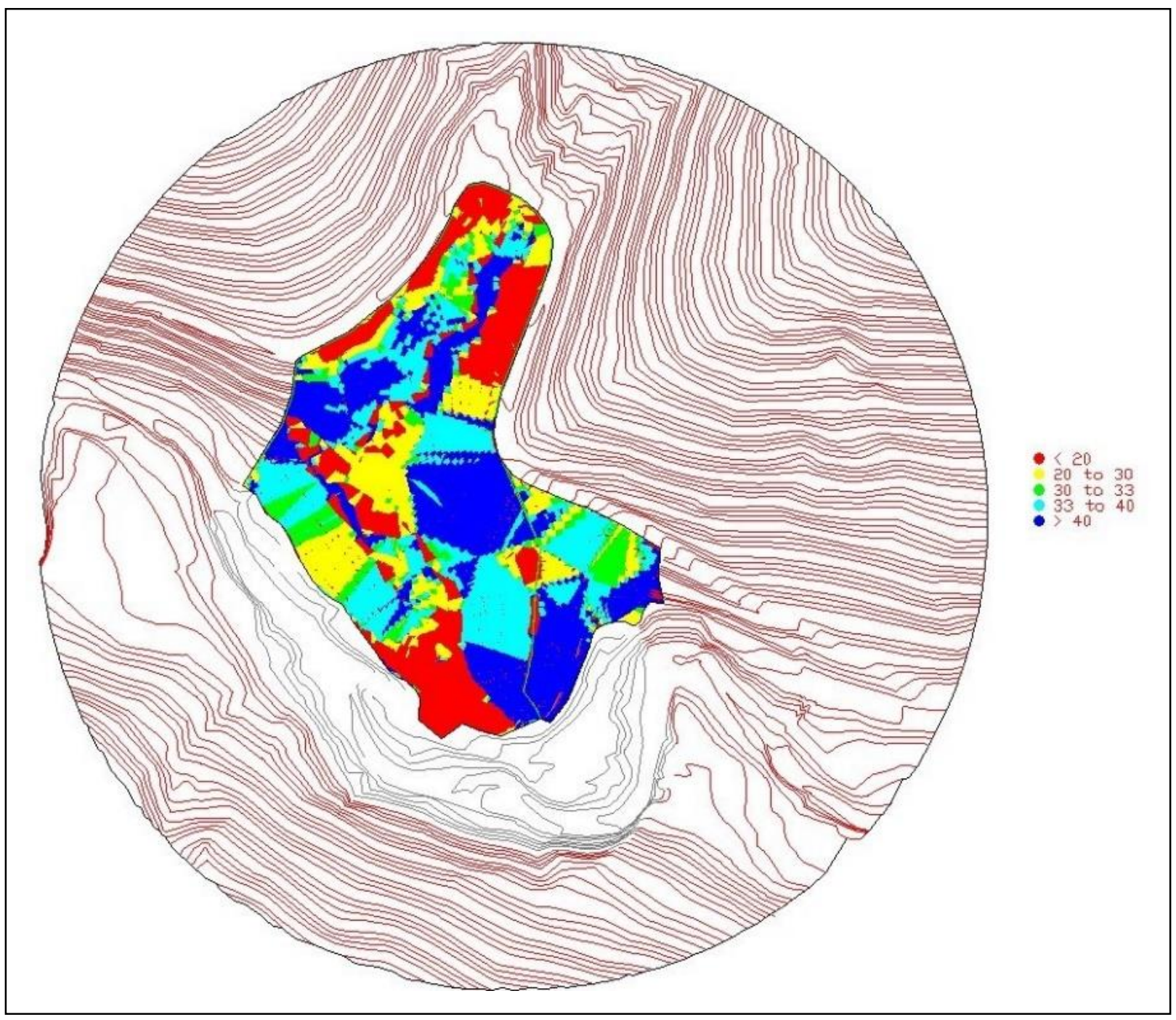

Figure 9. Slope zone of analysis of the Alternative \#2 fluvial geomorphic design with $71 \%$ of the slopes in the lower slope target steepness of $\leq 33$ percent. The actual design area for the reclamation design is 0.96 ha.

The site material balance shown in the cut fill color map view in Fig. 10 helps to visualize how the material movement can occur to facilitate the GET cover waste construction. The darkest red areas east and northeast of the reclamation channel alignment are where the maximum material cut is generated. The first cuts of that material can be placed against the west valley wall where the darkest blue indicates the maximum fill requirement. Placement of this material there reduces those slopes toward the target values. Then the GET cover can be constructed in the cut zone with its upper layers constructed of minimal thicknesses of onsite material segregated to meet the various layer specifications. 
Alternative \#2 holds promise for fully satisfying all the site design criteria in a final design for the reasons explained above. The next step in the design process will be to refine this landform design to better meet the slope targets and mitigate remaining erosive channel discharges and show how the GET cover is integrated into the landform.

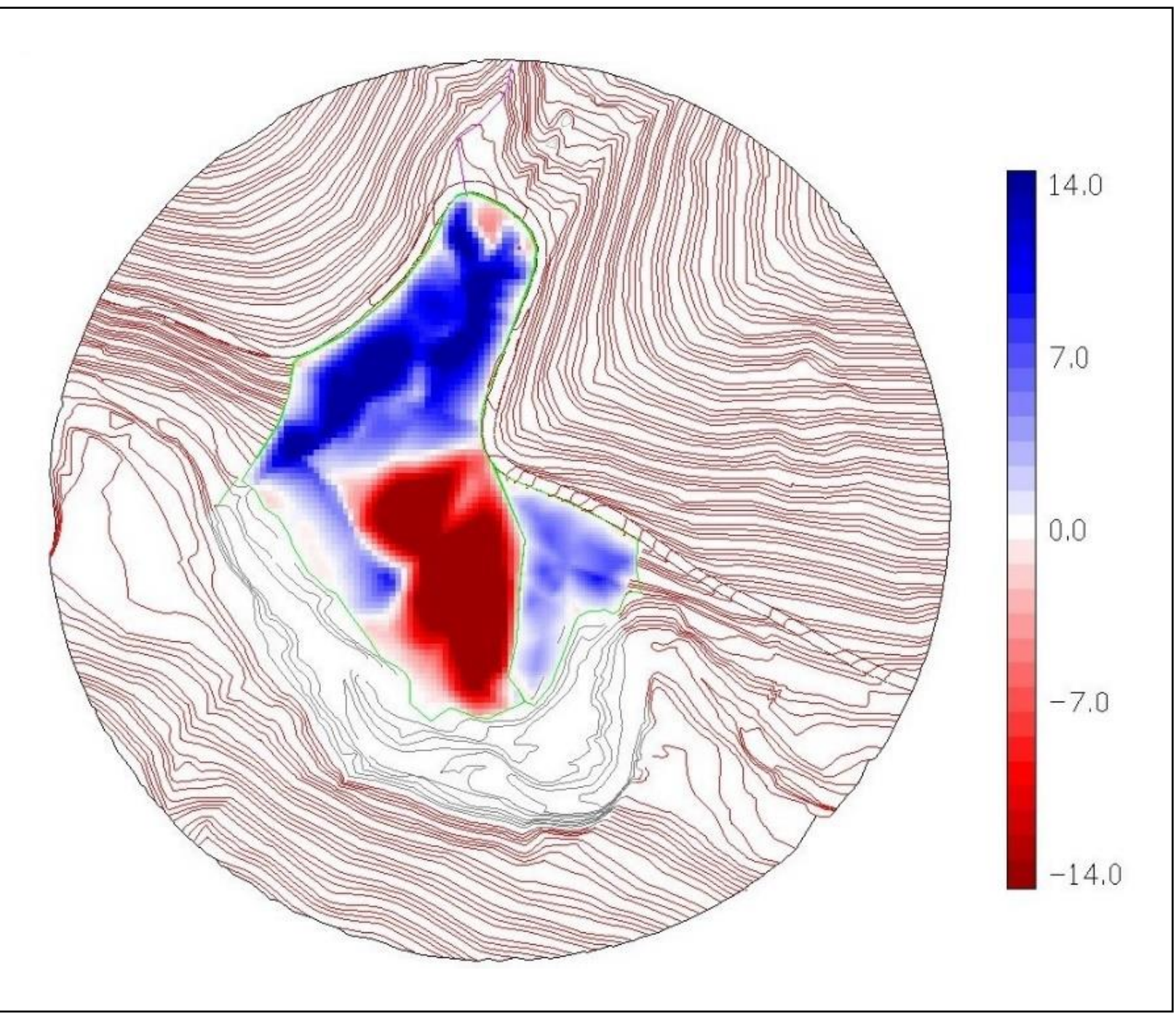

Figure 10. Cut fill color map of revised fluvial geomorphic design Alternative \#2. Positive values are for material fill and negative values for material cut. $T$ he actual design area for the reclamation design is 0.96 ha.

\section{$\underline{\text { Summary }}$}

This study proposed that covers can be designed by integrating two remediation technologies (geomorphic grading and ET cover) as a GET cover to improve the overall performance. The overall shape of the GET cover can mimic the natural topography of the surrounding area, while 
the thickness and layering of the cover can be optimized for best vegetation growth and infiltration control. Watershed groundwater flow is considered during GET cover design. The application of GET cover technology on mine land is expected to substantially improve the reclamation effects by coupling the benefits of the geomorphic cover (drainage reduction, runoff management, vegetation diversity) with the benefits of ET covers (vegetation growth and sustainability, percolation reduction, protection of surface and groundwater). A conceptual design study is carried out based on an actual, typical abandoned mine site near Raton, New Mexico, to which common problem conditions at abandoned mine sites are assumed. Specific designs of the GET covers will be evaluated in the late stage of this project.

\section{$\underline{\text { Acknowledgement }}$}

The work described in this publication was supported by Grant/Cooperative Agreement Number S17PG00002 from the Office of Surface Mining Reclamation and Enforcement (OSMRE). Its contents are solely the responsibility of the authors and do not necessarily represent the official views of the OSMRE.

\section{$\underline{\text { Literature Cited }}$}

Albright, W.H., C.H. Benson, G.W. Gee, A.C. Roesler, T. Abichou, P. Apiwantragoon, et al. 2004.

Field water balance of landfill final covers. Journal of Environmental Quality 33: 2317-2332. https://doi.org/10.2134/jeq2004.2317

Apiwantragoon, P., C.H. Benson, and W.H. Albright. 2015. Field hydrology of water balance covers for waste containment. Journal of Geotechnical and Geoenvironmental Engineering 141: 04014101. https://doi.org/10.1061/(ASCE)GT.1943-5606.0001195.

Arnold, J.G., R. Srinivasan, R.S. Muttiah, and J. R. Williams 1998. Large-area hydrologic modeling and assessment: Part I. Model development. J. Am. Water Resour. Assoc. 34: 73-89. https://doi.org/10.1111/j.1752-1688.1998.tb05961.x

Ayres, B., B. Dobchuk, D. Christensen, M. O'Kane, and M. Fawcett. 2006. Incorporation of Natural Slope Features into the Design of Final Landforms for Waste Rock Stockpiles. In: R. I. Barnhisel, editor, 7th International Conference on Acid Rock Drainage (ICARD). American Society of Mining and Reclamation (ASMR), St. Louis, MO. https://doi.org/10.21000/JASMR06020059 
Bailey, R.T., T.C. Wible, M. Arabi, R.M. Records, and J. Ditty. 2016. Assessing regional-scale spatio-temporal patterns of groundwater-surface water interactions using a coupled SWATMODFLOW model. Hydrol. Process. 30: 4420-4433. https://doi.org/10.1002/hyp.10933.

Barber, L.A., B.K. Ayres, and B.J. Schmid. 2015. Performance evaluation of reclamation soil cover systems at Cluff lake mine in northern Saskatchewan. In: A. B. Fourie, M. Tibbett, L. Sawatsky, and D. van Zyi, editors, Mine Closure 2015. 2015 InfoMine Inc., Vancouver, Canada. p. 929-938.

Barnswell, K.D. and D.F. Dwyer. 2011. Assessing the Performance of Evapotranspiration Covers for Municipal Solid Waste Landfills in Northwestern Ohio. Journal of Environmental Engineering 137: 301-305. https://doi.org/10.1061/(ASCE)EE.1943-7870.0000326.

Benson, C.H., T. Abichou, W.H. Albright, G.W. Gee, and A.C. Roesler. 2001. Field evaluation of alternative earthen final covers. International Journal of Phytoremediation 3: 105-127. https://doi.org/10.1080/15226510108500052

Benson, C.H., A. Sawangsuriya, B. Trzebiatowski, and W.H. Albright. 2007. Postconstruction changes in the hydraulic properties of water balance cover soils. Journal of Geotechnical and Geoenvironmental Engineering 133: 349-359. https://doi.org/10.1061/(ASCE)1090$\underline{0241(2007) 133: 4(349)}$

Bise, C.J. and R.E. Murray. 2013. The integration of geomorphic design into West Virginia Surface Mine Reclamation. West Virginia University, Morgantown, WV.

Borah, D.K., G. Yagow, A. Saleh, P.L. Barnes, W. Rosenthal, E.C. Krug, et al. 2006. Sediment and nutrient modeling for TMDL development and implementation. Trans. ASABE 49: 967986. https://doi.org/10.13031/2013.21742

Bowerman, G. and E.F. Redente. 1998. Biointrusion of Protective Barriers as Hazardous Waste Sites. Journal of Environmental Quality 27: 625-632. https://doi.org/10.2134/jeq1998.00472425002700030021x

Brady, K.B.C., M.W. Smith, and J. Schueck. 1998. Coal mine drainage prediction and pollution prevention in Pennsylvania. Pennsylvania Department of Environmental Protection, Harrisburg, PA.

Bugosh, N. 2004. Computerizing the fluvial geomorphic approach to land reclamation. In: R.I. Barnhisel, editor, 2004 National Meeting of the American Society of Mining and Reclamation and The 25th West Virginia Surface Mine Drainage Task Force. ASMR. p. 240-258. https://doi.org/10.21000/JASMR04010240 
Bugosh, N. 2006. Regional variations in stable landforms and how critical elements can be used to design reclamation landforms. In: R. I. Barnhisel, editor Billings Land Reclamation Symposium. BLRS and ASMR, Billings MT. p. 156-158.

Bugosh, N. 2009. A Summary of Some Land Surface and Water Quality Monitoring Results for Constructed GeoFluv Landforms. In: R.I. Barnhisel, editor, National Meeting of the American Society of Mining and Reclamation, Billings, MT, Revitalizing the Environment: Proven Solutions and Innovative Approaches. ASMR. https://doi.org/10.21000/JASMR09010153

Calle, M. and J. Stauffer. 2009. The Application of Geomorphic Reclamation Methods in Wyoming (Presentation). Geomorphic Reclamation and Natural Stream Design at Coal Mines, A Technical Interactive Forum. Bristol, VA.

CEAP. 2007. Conservation Effects Assessment Project. USDA Natural Resources Conservation Service, Washington, D.C.

Clark, D. 2008. Geomorphic Restoration: Case Studies of Success Over Time: Geomorphic Reclamation at the La Plata Mine, New Mexico. 30th Annual National Association of Abandoned Mine Land Programs Conference. Durango, CO.

Eckels, R. and N. Bugosh. 2010. Natural approach to mined land rehabilitation. Sydney, Australia. p. 11-16.

Freedman, V.L., M.D. Williams, C.R. Cole, M.D. White, and M.P. Bergeron. 2002. 2002 Initial Assessments for B-BX-BY Field Investigation Report (FIR): Numerical Simulations. Pacific Northwest National Laboratory, Richland, WA. https://doi.org/10.2172/15002644

Gassman, P.W., M. Reyes, C.H. Green, and J.G. Arnold. 2007. The Soil and Water Assessment Tool: Historical development, applications, and future directions. Trans. ASABE 50: 12111250. https://doi.org/10.13031/2013.23637

Gee, G.W., A.L. Ward, and M.J. Fayer. 1997. Surface barrier research at the Hanford Site. Land Contamination \& Reclamation 5: 233-238.

Hancock, G.R., R.J. Loch, and G.R. Willgoose. 2003. The design of postmining landscapes using geomorphic principles. Earth Surface Processes and Landforms 28: 1097-1110. https://doi.org/10.1002/esp.518.

Hopkinson, L., J. Quaranta, M. Armstead, J. Hause, and N. DePriest. 2012. Assessing Geomorphic Reclamation in Valley Fill Design for West Virginia. West Virginia University, Morgantown, WV. 
Link, S.O., N.R. Wing, and G.W. Gee. 1995. The Development of Permanent Isolation Barriers for Buried Wastes in Cool Deserts: Hanford, Washington. Journal of Arid Land Studies 4: 215224.

Meiers, G., M. O’Kane, D. Mayich, P. Weber, C. Bradley, and J. Shea. 2015. Closure of legacy waste rock piles: can we achieve passive treatment to manage residual seepage in the short term? In: A.B. Fourie, M. Tibbett, L. Sawatsky and D. van Zyi, editors, Mine Closure 2015. InfoMine Inc., Vancouver, Canada. p. 965-979.

Nicolau, J.M. 2002. Runoff generation and routing on artificial slopes in a Mediterranean continental environment: the Teruel coalfield, Spain. Hydrological Processes 16: 631-647. https://doi.org/10.1002/hyp.308.

Nicolau, J.M. 2003. Trends in relief design and construction in opencast mining reclamation. Land Degradation \& Development 14: 215-226. https://doi.org/10.1002/ldr.548.

Nicolau, J.M. and E. Asensio. 2000. Rainfall erosion of opencast coal-mine lands: ecological perspective. In: M.J. Haigh, editor, Reclaimed Land: Erosion Control, Soils and Ecology. Balkema, Rotterdam. p. 51-73.

O'Kane, M. and C. Wels. 2003. Mine Waste Cover System Design — Linking Predicted Performance to Groundwater and Surface Water Impacts. In: T. Farrell and G. Taylor, editors, 6th International Conference on Acid Rock Drainage (ICARD). Cairns, Queensland.

Osterkamp, W.R. and W.L. Joseph. 2000. Climatic and hydrologic factors associated with reclamation. In: R. Barnhisel, R. Darmody, and W. Daniels, editors, Reclamation of Drastically Disturbed Lands. American Society of Agronomy, Madison WI. p. 193-216.

Pettit, P.J., D. Ridenour, J. Walker, and K. Saugier. 1994. Demonstration of in situ-constructed horizontal soil containment barrier at Fernald. Fernald Environmental Management Project, Cincinnati, Ohio. p. Medium: ED; Size: 6 p.

Rumer, R.R. and M.E. Ryan. 1995. Barrier Containment Technologies for Environmental Remediation Applications. Wiley, John \& Sons, Inc., New York, NY.

Rutqvist, J., H.-H. Liu, C.I. Steefel, M.A. Serrano de Caro, F.A. Caporuscio, J.T. Birkholzer, et al. 2011. Disposal systems evaluations and tool development : Engineered Barrier System (EBS) evaluation. P. Medium: ED; Size: 204 p. https://doi.org/10.2172/1011667 
Santini, T.C. and M.V. Fey. 2014. Fly ash as a permeable cap for tailings management: pedogenesis in bauxite residue tailings. Journal of Soils and Sediments 15: 552-564. https://doi.org/10.1007/s11368-014-1038-6.

Scanlon, B.R., W.F. Mullican, R.C. Reedy, and E.S. Angle. 1997. Prototype engineered barrier designs for low-level radioactive waste disposal in Texas. In: T.D. Reynolds and R.C. Morris, editors, Landfill Capping in the Semi-Arid West: Problems, Perspectives, and Solutions. Environmental Science and Research Foundation, Idaho Falls, ID. p. 231-242.

Scanlon, B.R., R.C. Reedy, D.A. Stonestrom, D.E. Prudic, and K.F. Dennehy. 2005. Impact of land use and land cover change on groundwater recharge and quality in the southwestern US. Global Change Biology 11: 1577-1593 https://doi.org/10.1111/j.1365-2486.2005.01026.x

Schor, H.J. and D.H. Gray. 2007. Landforming: an Environmental Approach to Hillside Development, Mine Reclamation and Watershed Restoration. John Wiley and Sons, Inc., Hoboken, NJ. https://doi.org/10.1002/9780470259900

Waugh, W.J., C.H. Benson and W.H. Albright. 2010. Sustainable Covers for Uranium Mill Tailings, USA: Alternative Design, Performance, and Renovation. Proceedings of the 12th International Conference on Environmental Remediation and Radioactive Waste Management, Liverpook, UK. October 11-15, 2009. Liverpool, UK.

Waugh, W.J., G. Smith, B. Danforth, G.W. Gee, V. Kothari, and T. Pauling. 2007. Performance Evaluation of the Engineered Cover at the Lakeview, Oregon, Uranium Mill Tailings Site. Proceedings of Waste Management 2007. Tucson, AZ.

White, M.D., D. Appriou, D.H. Bacon, Y. Fang, V.L. Freedman, M.L. Rockhold, et al. 2015. STOMP/eSTOMP User Guide. PNNL-SA-108766. Pacific Northwest National Laboratory, Richland, WA.

Wing, N.R. and G.W. Gee. 1994. Quest for the perfect cap. Civil Engineering 64: 38-41.

Zhan, G., W. Schafer, M.A. Milczarek, K. Myers, J. Giraudo, and R. Espell. 2006. The evolution of evapotranspiration cover systems at Barrick Goldstrike mines. 7th ICARD. ASMR, St. Louis, MO. pp 2585-2603 https://doi.org/10.21000/JASMR06022585

Zhang, Z.F. 2015. Field Soil Water Retention of the Prototype Hanford Barrier and Its Variability with Space and Time. Vadose Zone Journal 14: 1-10. https://doi.org/10.2136/vzj2015.01.0011 
Zhang, Z.F., V.L. Freedman, and S.R. Waichler. 2004. 2004 Initial Assessments for the T and TXTY Tank Farm Field Investigation Report (FIR): Numerical Simulations. PNNL-14838. Pacific Northwest National Laboratory, Richland, WA. https://doi.org/10.2172/15020755

Zhang, Z.F., V.L. Freedman, S.R. Waichler, and S.K. Wurstner. 2005. 2005 Closure Assessments for S-SX Tank Farms: Numerical Simulations. PNNL-15399. Pacific Northwest National Laboratory, Richland, WA.

Zhang, Z.F., V.L. Freedman, and M.D. White. 2003. 2003 Initial Assessments of Closure for the C Tank Farm Field Investigation Report (FIR):Numerical Simulations. PNNL-14334. Pacific Northwest National Laboratory, Richland, WA. https://doi.org/10.2172/15010539

Zhang, Z.F. and Y. Xie. 2006. 2006 Initial Assessments for the A-AX, C and U Tank Farms Field Investigation Report (FIR): Numerical Simulations. PNNL-SA-51956. Pacific Northwest National Laboratory, Richland, WA. 